\title{
Abdulhamid Abdussaid
}

\section{January 1932-14 December 2016}

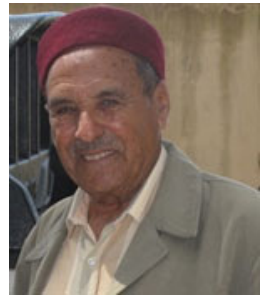

It is with great sadness that we report the death of the much admired and greatly respected Libyan archaeologist, Abdulhamid Abdussaid.

Abdulhamid Abdussaid was born in Shahat in 1932. He spent his formative years amongst the ruins of Cyrene, where his father was employed by the Italian Soprintendenza excavating and restoring buildings in the Sanctuary of Apollo and around the Agora. Here, with a backdrop of stunning ruins, beautiful scenery and exciting new discoveries, from a very early age he developed a great passion for Cyrene and a vocation in archaeology.

The war years brought an end to excavation and restoration at Cyrene and heralded a long period of inactivity on the site. As a teenager, Abdulhamid witnessed the return of material taken away from Cyrene for safety and with his father helped to secure the site, even though an antiquities service was no longer active at that time. It was only after Libya gained her independence in 1951 that a Controller of Antiquities in Cyrenaica (C. N. Johns) was appointed and activities were renewed. But it was not until 1953 when the Libyan government appointed Richard Goodchild to the Controllership that archaeological work on any scale was put in progress. Within this context, it did not take too long for Richard Goodchild to discover this shrewd, hardworking young man, who by then had a good knowledge of Italian and English.

Abdulhamid rapidly became one of Goodchild's most able and reliable assistants, right up until Goodchild gave up his post in 1966. He took part in a number of Goodchild's projects in the country districts of Cyrenaica (including ancient Balagrae, Lamluda and Gasr Lebia) and in addition to Goodchild's own projects at Cyrene, he assisted an Italian expedition led by Professor Sandro Stucci working in the Agora, with British excavations within the Caesareum and the Temple of Zeus and with the work of J. S. Cassels, Alan Rowe and R. A. Tomlinson in the Necropolis of Cyrene. The days working with Goodchild were never forgotten and it has always been clear to all those who reminisced with Abdulhamid, right up until the end of his life, that his work in the fifties was not only a seminal time in his development as a Libyan archaeologist and scholar, but the very best of times.

In 1957, Abdulhamid was awarded a UNESCO scholarship, enabling him to travel to Italy, the Lebanon and Greece. On his return in 1958, he was appointed Inspector in the Office of the Department Antiquities of the Eastern Province of Libya. In August 1958, he accompanied D. C. Rice, a specialist in Islamic epigraphy, to study Kufic inscriptions recently found in al-Merj. Soon after this, he was awarded a British Council scholarship to attend a six-month training course in conservation.

Following the short mission with Rice, Abdulhamid developed a deep interest in Islamic archaeology. He took part in numerous excavations and surveys in different parts of Libya. In the early 1960s he investigated Islamic monuments in Ajdabiyah (Libya Antiqua I, 1964) and later directed excavations at Medinat Sultan, where he discovered its early mosque (Libya Antiqua III-IV, 1966-67). Closer to home, he conducted investigations at the ancient site of Barce (modern al-Merj), where Kufic inscriptions were found (Libya Antiqua VIII, 1971), and in 1978 he directed excavations at the white mosque in Zwela (Libya Antiqua XIV-XVI, 1979). At this time, as head of technical affairs in the Department of Antiquities of Shahat, together with a group of staff members, he undertook an important archaeological survey in the Wadi al-Kuf area in advance of a proposal to establish a national park there.

In 1971 Awad Sadawiya, Director General of Antiquities in Libya, appointed Abdulhamid as Controller of the new Department of Antiquities in Benghazi. Almost immediately, Abdulhamid, with the support of Ali Salem Letrik and working in concert with Ward-Perkins and Donald Strong, encouraged the mounting of an emergency excavation at Sidi Khrebish, part of ancient Berenice, then under development, and did all in his power to ensure the success of the initiative. This first joint programme of archaeological fieldwork between the Department of Antiquities in the Libyan Arab Republic and the newly formed Society for Libyan 
Studies continued under the direction of John Lloyd until 1974 (Supplements Libya Antiqua V).

A major turning point in Abdulhamid's career occurred following the death of Awad Sadawiya and senior antiquities staff when Libyan Arab Airlines flight 114 taking the party to a conference was shot down over the Sinai Peninsula in 1973. This tragic loss left the Department rudderless and deprived of leadership. Abdulhamid was amongst a small cadre of senior staff asked to fill the vacuum and he was appointed Director of Technical Affairs in Tripoli. In this post, he helped to initiate a series of ambitious scientific projects and training programmes, including the UNESCO Libyan Valleys Archaeological Survey and, again with help from UNESCO, the establishment of a new national museum in Tripoli. With a background in archaeological fieldwork and with his fluency in English and Italian, he was later entrusted with overseeing the work of all foreign archaeological missions working in Libya.

Even in retirement, when a decision was made to restore two mausoleums in remote areas of the predesert zone of Tripolitania, in difficult conditions and with poor access, Abdulhamid was asked to undertake the projects. In the event, and true to the man's organisational and leadership skills, the

Head of Mission, Society for Libyan Studies

University of Leicester, UK work was perfectly done; when the first restoration was completed in the northern part of the Wadi Nfed (Libya Antiqua II, 1996), the second at Bir et-Uaar, near al-Urban in Gebel Garian (Libya Antiqua IV, 1998), was begun and completed.

Over his long years of service and in retirement, Abdulhamid represented the Libyan Department of Antiquities at numerous regional and international conferences and brought considerable knowledge, acumen, gravitas and charm to such occasions, together with great credit to the Department and to Libyan scholarship. Throughout his long and active life, even deep into his retirement as a greatly loved and respected tourist guide, and towards the end of his life, he was dedicated to his work. Diligence, commitment and punctuality were hallmarks deeply engraved in his personality. When put under pressure or in periods of crisis, he was at all times a bastion of calm. He was a Libyan landmark; a greatly respected man of ability, charisma, great charm, with a wry sense of humour, who devoted most of his life to serving and preserving Libya's precious archaeological heritage.

Abdulhamid Abdussaid died in his beloved Shahat on 14 December 2016 at the age of 84 . His legacy will endure.
Paul Bennett

Ahmed Buzaian 